\title{
Case report: absence of the right piriformis muscle in a woman
}

\author{
Erich Brenner ${ }^{1}\left(\mathbb{D} \cdot\right.$ Massimiliano Tripoli $^{2} \cdot$ Elia Scavo $^{2} \cdot$ Adriana Cordova $^{2,3}$
}

Received: 1 October 2018 / Accepted: 26 December 2018 / Published online: 13 February 2019

(c) The Author(s) 2019

\begin{abstract}
We report a very rare case of a unilaterally absent piriformis muscle in a 60 year old woman. Accompanying variations comprised a common gluteal artery (instead of two distinct superior and inferior gluteal arteries), and an absent gemellus inferior muscle. The contralateral left side showed a normally developed piriformis muscle. In hominoids, the piriformis is constant, but is regularly missing in several other vertebrates. The piriformis muscle is an anatomical landmark for ultrasound investigations and ultrasound-guided interventions in the deep gluteal region such as a superior gluteal nerve block or even a sacral plexus block, also for any surgical approach such as total hip arthroplasty. A missing piriformis muscle therefore affects the orientation in the deep gluteal region and therefore the identification of the targeted structures.
\end{abstract}

Keywords Piriformis muscle · Anatomical variation · Deep gluteal region · Common gluteal artery · Gemellus inferior muscle $\cdot$ Anatomical variation

\begin{tabular}{|c|c|}
\hline \multicolumn{2}{|c|}{ Abbreviations } \\
\hline gi & Gemellus inferior muscle \\
\hline gs & Gemellus superior muscle \\
\hline $\operatorname{tg}_{\max }$ & Gluteus maximus muscle \\
\hline$g_{\text {med }}$ & Gluteus medius muscle \\
\hline $\mathrm{g}_{\min }$ & Gluteus minimus muscle \\
\hline igv & Inferior gluteal vein \\
\hline ipa & Internal pudendal artery \\
\hline ipv & Internal pudendal vein \\
\hline oi & Obturator internus muscle \\
\hline $\mathrm{pm}$ & Piriformis muscle \\
\hline $\mathrm{pfc}$ & Posterior femoral cutaneous nerve \\
\hline $\mathrm{pn}_{1}, \mathrm{pn}_{2}$ & Doubled pudendal nerve \\
\hline st & Sacrotuberal ligament \\
\hline sn & Sciatic nerve \\
\hline cga & Common gluteal artery \\
\hline $\operatorname{gv}$ & Superior gluteal vein \\
\hline
\end{tabular}

Erich Brenner

Erich.Brenner@i-med.ac.at

1 Division of Clinical and Functional Anatomy (Director: o.Univ.Prof. Dr. H. Fritsch), Medical University of Innsbruck, Muellerstrasse 59, 6020 Innsbruck, Austria

2 Chirurgia Plastica Ricostruttiva ed Estetica, Policlinico 'Paolo Giaccone' di Palermo, Palermo, Italy

3 Department of Surgical Oncological and Oral Science (DiChiRonS), Palermo University, Palermo, Italy

$\begin{array}{ll}\mathrm{t} & \text { Greater trochanter } \\ \mathrm{i} & \text { Ischial tuberosity }\end{array}$

\section{Introduction}

The piriformis muscle is clinically well known for the compression of the sciatic nerve, the piriformis (muscle) syndrome or deep gluteal syndrome [11].

Related on this pathology, a vast amount of studies investigated the relationship between the piriformis muscle and the sciatic nerve, reporting the variability of the piriformis muscle mainly according to the classification by Beaton and Anson [3]. None of these studies reported an absent or missing piriformis muscle (e.g. [18]). Also fetal studies found a constant piriformis muscle (e.g. [2]).

The literature provides only few reports on a missing piriformis muscle. Alexander Macalister found one case and reported this very case at least three times (e.g. Ref. [9]). Furthermore, Macalister cites case reports by Otto and Budge: in the subject dissected by Budge the lower limb was deformed [9], and in the specimen dissected by Otto the gemellus superior was very large [9]. These last observations are not sufficiently known for us to judge whether it was actually a real absence of the piriformis muscle or simply the fusion with one of the neighboring muscles, such as the gemellus superior or the gluteus medius muscles. The extensive compilation on anatomical variations of the piriformis 
muscle by Nicholson et al. [12] reports erroneously a paper, which should have described two missing piriformis muscles out of six specimens; nevertheless, that paper [5] describes six piriformis muscles in six specimens, whereas the gemellus superior was missing in two, and the gemellus inferior in one case.

\section{Case report}

We report here the case of a 60 -year old Caucasian woman who died from amyotrophic lateral sclerosis. She donated her body to the anatomical department giving informed consent for using her body for scientific and educational purposes prior to death [14]. At admission a $30 \mathrm{~cm}$ scar was found at the left lateral thigh, and another $10 \mathrm{~cm}$ transversal collar scar. No further medical data are available. Her corpse was preserved using an arterial injection of a formaldehyde-phenol solution and immersed in phenolic acid in water for 3 months [13].

The corpse was used for a surgical-anatomical study on the superficial and subfascial vascularity of the gluteal region. When dissecting the right side and detaching the gluteus maximus muscle to display the gluteal arteries and veins no piriformis muscle could be found.

\section{Description}

The greater sciatic foramen is properly formed by the greater sciatic notch, the sacrotuberal and the sacrospinal ligaments. Only neurovascular structures pass, a common gluteal artery (replacing the superior gluteal artery), a superior gluteal vein, the sciatic nerve, an inferior gluteal vein, a (bipartite) pudendal nerve and the internal pudendal vessels. In other words, the piriformis muscle is missing as well as the inferior gluteal artery. Both, a vessel resembling the 'descending branch of the inferior gluteal artery' and the artery to the sciatic nerve originate from the common gluteal artery. Furthermore, at the lesser sciatic foramen, a quite large gemellus superior muscle accompanies the obturator internus muscle, whereas the gemellus inferior muscle is also missing (Fig. 1).

The left side shows no variations; the piriformis muscle exists.

\section{Discussion}

As this case seems to be the second 'verified' throughout literature we have to discuss carefully possible probabilities such as (complete) fusion with another muscle, the (complete) involution or atrophy due to a medical intervention, or a real aplasia.

\section{Fusion with another muscle}

The piriformis muscle might fuse more or less completely with the gluteus medius, the gluteus minimus or the gemellus superior muscles, respectively. None of these is the case here.
Fig. 1 Right deep gluteal region with absent piriformis muscle (female, 60 years)

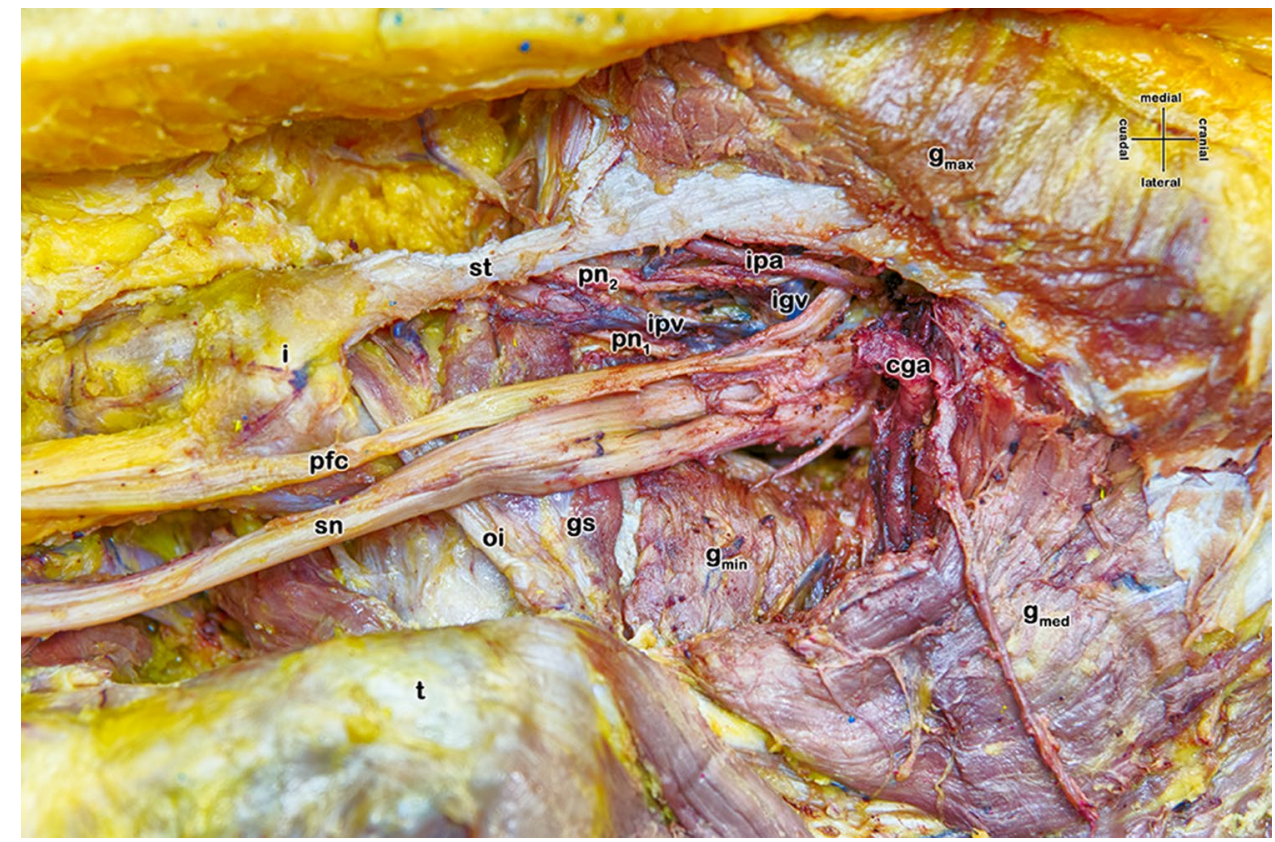




\section{Involution due to a medical intervention}

Medical interventions for the treatment of piriformis muscle syndrome include methods such as botulinum toxin injections [1], surgical or endoscopic transection, i.e., tenotomy [8], or rupture during total hip arthroplasty [15]. Al-AlShaikh et al. [1] showed that tenotomy of the piriformis muscle leads to atrophy and fatty infiltration, but not to a complete disappearance. Furthermore, other authors argue that tenotomy might even increase the symptoms of piriformis muscle syndrome (post-tenotomy sciatica) due to retraction of the piriformis muscle [17].

\section{Real aplasia}

This is the most probable reason.

\section{Clinical relevance}

The piriformis muscle is an anatomical landmark for ultrasound investigations and ultrasound-guided interventions in the deep gluteal region such as a superior gluteal nerve block or even a sacral plexus block. Furthermore, the piriformis muscle is an important guide for any posterior surgical approach such as total hip arthroplasty. A missing piriformis muscle therefore affects the orientation in the deep gluteal region and therefore the identification of the targeted structures. Of course, the diagnosis of a piriformis syndrome and related interventions would be obsolete in a further patient with an absent piriformis muscle.

\section{Comparative anatomy}

In all hominoids the piriformis originates from the anterior surface of the sacrum, as well as from its lateral aspect, and inserts onto the greater trochanter of the femur [7]. In Babirusas, also called deer-pigs, this muscle has fused completely with the M. gluteus medius [10]. The piriformis of human anatomy differs in origin from that of the elephant, where it arises dorso-laterally from the sacral vertebrae close to the tuber sacrale of the ilium, and blends both with the superficial and middle glutei [6]. Based on the literature, the piriformis muscle is absent in several vertebrates, such as solipeds, ruminants, porks, macaques, spider monkeys, coati, bats, etc. [16]. The deep gluteal anlage, i.e., the gluteus medius, gluteus minimus and piriformis, is clearly homologous to the lizard iliofemoralis because in both groups this anlage has an acetabular bony origin, a proximal insertion, and a position posterior to the fibular nerve trunk [4].

Acknowledgements Open access funding provided by University of Innsbruck and Medical University of Innsbruck. The authors wish to thank this individual who donated her body and tissues for the advancement of education and research. We gratefully acknowledge the careful photographic documentation of the reported variation by Romed Hörmann, Division of Clinical and Functional Anatomy, Medical University of Innsbruck.

Author contributions $\mathrm{AC}$ and $\mathrm{EB}$ designed the surgical-anatomical study on the superficial and subfascial vascularity of the gluteal region. AC, ES, MT performed the dissections in this study; EB finished dissection of this reported variation. EB drafted the manuscript; AC, ES, MT edited the manuscript. All authors approved the final manuscript.

Open Access This article is distributed under the terms of the Creative Commons Attribution 4.0 International License (http://creativeco mmons.org/licenses/by/4.0/), which permits unrestricted use, distribution, and reproduction in any medium, provided you give appropriate credit to the original author(s) and the source, provide a link to the Creative Commons license, and indicate if changes were made.

\section{References}

1. Al-Al-Shaikh M, Michel F, Parratte B, Kastler B, Vidal C, Aubry $S$ (2015) An MRI evaluation of changes in piriformis muscle morphology induced by botulinum toxin injections in the treatment of piriformis syndrome. Diagn Interv Imaging 96:37-43. https://doi. org/10.1016/j.diii.2014.02.015

2. Aydın Kabakcı AD, Buyukmumcu M, Yılmaz MT, Cicekcibasi AE, Akin D (2016) Anatomical structure and topographic anatomy of sciatic nerve in human fetuses. J Anat Soc India 65:S25S32. https://doi.org/10.1016/j.jasi.2015.12.001

3. Beaton LE, Anson BJ (1937) The relation of the sciatic nerve and of its subdivisions to the piriformis muscle. Anat Rec 70:1-5. https://doi.org/10.1002/ar.1090700102

4. Diogo R, Molnar J (2014) Comparative anatomy, evolution, and homologies of tetrapod hindlimb muscles, comparison with forelimb muscles, and deconstruction of the forelimb-hindlimb serial homology hypothesis. Anat Rec 297:1047-1075. https://doi. org/10.1002/ar.22919

5. Duda GN, Brand D, Freitag S, Lierse W, Schneider E (1996) Variability of femoral muscle attachments. J Biomech 29:1185-1190. https://doi.org/10.1016/0021-9290(96)00025-5

6. Eales NB (1928) XXV.- the anatomy of a Fœtal African Elephant, Elephas africanus (Loxodonta africana). Part II. The body muscles. Earth Environ Sci Trans R Soc Edinb 55:609-642

7. Ferrero EM, Pastor JF, Fernandes FDP, Cachorro MB, Diogo R, Wood B (2012) Comparative anatomy of the lower limb muscles of hominoids: attachments, relative weights, innervation, functional morphology and evolution. In: Hughes EF, Hill ME (eds) Primates: classification, evolution and behaviour. Nova Science Publishers, Hauppauge, pp 1-70

8. Ilizaliturri JVM, Arriaga R, Villalobos FE, Suarez-Ahedo C (2018) Endoscopic release of the piriformis tendon and sciatic nerve exploration. J Hip Preserv Surg 5:301-306. https://doi. org/10.1093/jhps/hny018

9. Macalister A (1875) Additional observations on muscular anomalies in human anatomy (third series), with a catalogue and the principal muscular variations hitherto. Trans R Ir Acad Sci 25:1-130

10. Macdonald AA, Kneepkens AFLM (1995) Descriptive and comparative myology of the hindlimb of the Babirusa (Babyrousa babyrussa L. 1758). Anat Histol Embryol 24:197-207. https:// doi.org/10.1111/j.1439-0264.1995.tb00035.x

11. Murakami M, Kirschner J (2018) Piriformis syndrome. In: Kahn SB, Xu RY (eds) Musculoskeletal sports and spine disorders: a 
comprehensive guide. Springer, Cham, pp 231-235. https://doi. org/10.1007/978-3-319-50512-1_51

12. Nicholson H, Woodley S, Flack N (2016) Gluteal muscles and lateral rotators of the hip. In: Tubbs RS, Shoja MM, Loukas M (eds) Bergman's comprehensive encyclopedia of human anatomic variation. Wiley, Hoboken, pp 386-409. https://doi.org/10.1002/97811 18430309.ch39

13. Platzer W, Putz R, Poisel S (1978) Ein neues Konservierungsund Aufbewahrungssystem für anatomisches Material. Acta Anat (Basel) 102:60-67

14. Riederer BM, Bolt S, Brenner E, Bueno-Lopez JL, Chirculescu ARM, Davies DC, De Caro R, Gerrits PO, McHanwell S, Pais D, Paulsen F, Plaisant O, Sendemir E, Stabile I, Moxham BJ (2012) The legal and ethical framework governing body donation in Europe-1st update on current practice. Eur J Anat 16:1-21
15. Solomon LB, Naal FD, Howie DW (2013) Piriformis muscle rupture during total hip arthroplasty using a muscle-preserving posterior approach. Acta Orthop Belg 79:616-619

16. Testut L (1884) Les anomalies musculaires chez l'homme: expliquées par l'anatomie comparée leur importance en anthropologie. G. Masson, Paris

17. Tomaszewski KA, Graves MJ, Henry BM, Popieluszko P, Roy J, Pekala PA, Hsieh WC, Vikse J, Walocha JA (2016) Surgical anatomy of the sciatic nerve: a meta-analysis. J Orthop Res 34:1820-1827. https://doi.org/10.1002/jor.23186

18. van Erdewyk JI (2017) Anatomical variations of the sciatic nerve divisions in relation to the piriformis muscle and clinical implications. Theses \& Dissertations, 194. University of Nebraska Medical Center, Omaha. http://digitalcommons.unmc.edu/etd/194 